UDC: 37.01

DOI: https://doi.org/10.24195/2414-4665-2020-4-1

\author{
Zeynab Mehdyeva, \\ Teacher of Nakhchivan Teachers' Institute, \\ 1, Heydar Aliyev Street, Nakhchivan, Republic of Azerbaijan
}

\title{
THE USE OF ACTIVE WORK FORMS IN THE INCULCATING THE LIFE SKILLS
} AMONG YOUNGER STUDENTS

The experience of using active forms of work in inculcating life skills in students in the primary grades of secondary schools was widely analyzed in the article. The types of lessons are classified, in which the essence of the types of active lessons is clarified. It is noted that it is possible to achieve the formation of students' life skills through the use of active forms of work in the learning process organized for all types of modern lessons. For this, it is necessary to create motivation in the course of an active lesson, to use problem situations. We know that training mainly motivates thinking. Setting a task for students motivates them to think and creates conditions for the formation of their thinking. By solving the problem, children develop positive emotions and enthusiasm for learning. The use of the active work forms in the inculcation of life skills also creates the basis for enhancing students' cognitive activity. In this regard, it is also important to perform problematic tasks. Thus, creating the basis for the acquisition of new knowledge and creating conditions for active understanding of knowledge plays a key role in the implementation of problematic tasks. The article summarizes the use of interactive teaching methods, and also focuses on the main aspects of the activity process of the primary school teachers. Thus, the article reflects the use of active forms of work in the process of teaching the subject "life knowledge" in the disclosure of life skills of students.

Keywords: Primary school, student, interactive teaching method, life skills, active work forms, school, lesson.

\section{Introduction and the current state of the research problem}

In the primary grades the inculcation of life skills in students is of great importance. Because it is necessary to use the most modern forms of active works to create a new content of personality-oriented education in the state directives on education reform in the Republic of Azerbaijan, including the "State Strategy for the Development of Education in Azerbaijan." Study programs successfully implemented in our country recommend that students be taught life skills in the process of teaching subjects. The use of active forms of work for this purpose has a dynamic impact on instilling in students the most necessary life skills.

Lesson is the most important of active forms of work, dynamically influencing the formation of life skills of primary school students. Lessons are the most active form of learning, carried out under the guidance of a teacher, within a certain period of time, on the basis of the curriculum. So, one of the most active forms of work that plays an important role in inculcating life skills in primary school students is lesson. That is why the lesson is considered one of the active forms of teaching in the teaching of life sciences, along with the teaching of all subjects. In addition to teaching all subjects, teaching of Life knowledge also provides ample opportunities for developing life skills in young students through active forms of learning.

\section{Purpose of the Study}

It consists of determining the content, form and methods of using active forms of work in primary school students, substantiating them theoretically and checking their effectiveness.

\section{Research tasks}

The objectives of the study are as follows:

1. To clarify the content and pedagogicalpsychological features of the work on the subject of life knowledge;
2. To study the didactic bases of the subject of life knowledge in primary school, the problem in the curriculum and teaching aids;

3. To determine the current situation with the problem of teaching life skills in educational institutions;

4. To systematize the methods and means of teaching labor skills and ensuring children's cognitive activity during the organization of active forms of work in primary school;

5. To reveal the forms and methods of joint work of the kindergarten and the family in the formation of active work in primary school;

\section{Research methods}

The following methods were used in the research process:

1. Scientific analysis - the situation with the teaching of life sciences by teachers in schools is analyzed.

2. Observation - students' life skills are observed in schools.

3. Interview - students are asked questions about the level of learning the subject of life skills.

\section{Research results} research:

The following results were obtained from the

1. In order to ensure the formation of active work in students in primary school, first of all, it is necessary to study their level of skills in this area, to take it into account in the later stages.

2. It is expedient to gradually expand the organization of active work in primary school on the formation of active work in students, based on the peculiarities of children's daily social life.

3. The formation of active work in students of active work in primary school in their training serves the preparation, upbringing and development.

4. The result of active work in primary school on the formation of active work in students is not scattered, 
retail, but planned, microsystems, each time work is carried out in one area of work, labor skills are interconnected becomes efficient.

5. Effective work in primary school is most effective when a variety of forms, tools, interactive methods and new technologies, special walks and excursions, practical work and children's observations are widely used for the correct and intensive formation of active work in students.

\section{Discussions}

The following provisions are discussed in the article:

1. The role of determining the pedagogical and psychological basis of the process in the formation of active work in students in primary school is great.

2. Systematic study of the content, methods and techniques of active work in the formation of active work in students in primary school is an important condition for achieving high results.

3. The formation of active work in students in primary school The application of forms of organization of the subject of life knowledge ensures the effectiveness of work.

4. Defining a system of work on the formation of active work in students in primary school, creates favorable conditions for the participation of children in various types of work and the formation of skills in the subject of life skills.

The process of inculcating life skills in primary school students

The knowledge, skills and habits given to students in primary school should play a key role in the formation of high human qualities. First of all, at the completion of education a child should leave the school as a good person and be a well-trained, skilled specialist. From the very first steps acting as a person who has mastered national, moral and universal values and formed life skills, he/she must adapt to socio-political life in society, a market economy, and a rich information and communication space.

Different methods are used in the teaching of Life Knowledge, which is an integrative subject, and these methods also play an important role in the formation of various skills in students. The use of teaching methods at each stage of the lesson creates conditions for a more effective implementation of the active form of training.

Types of lessons used to instill life skills in primary school students

The choice of types of lessons for the formation of life skills in students is also considered useful in the process of teaching life skills. Educational practice has confirmed that the main form of teaching in general education schools is the lesson. A lesson is a form of action in which the content, principles and methods of teaching are provided, planned and regulated by the teacher within a certain period of time, and and manifests itself as a set of relationships between teacher and student. A lot of research works done to improve the course, and this process is ongoing; its types and structure are specified, the theory and practice of organization and management of the training material are developed at a level that can play the role of a form of procedural action. However, there is still no consensus on the issues related to the lesson.

There are the following types of lessons:
1. A Lesson, providing assimilation of new material;

2. A Lesson, providing knowledge and skills; habits;

3. A Lesson that improves knowledge, skills and

4. A Lesson that checks the level of knowledge and skills development;

5. A Test course, which serves to check the level of the system of knowledge, skills and habits;

6. Practical lesson mainly dedoted icated to practical activities;

7. Work lesson organized on the basis of new pedagogical technologies;

8. Lesson of repetition, which mainly serves the repetitive comprehension of the given knowledge;

9. Lessons based on school lectures;

10. Mixed lesson and combined lesson (Huseynzade, 2013: 127).

In the process of teaching each of these types of lessons, there are ample opportunities to instill life skills in students. These opportunities need to be exploited when trying to create the motivation needed to develop life skills. If it is necessary to activate students at the first stage of the lesson when organizing a lesson that ensures the assimilation of new materials, it is necessary to activate students at all stages in the process of organizing a lesson that ensures the formation and improvement of their knowledge. It is useful to organize the activation phase as appropriate in the process of applying the test lesson, practical lesson, study lesson, review lesson, school lecture, mixed lesson and combined lesson types.

Skills are directly related to the content of knowledge. Each of the skills is based on a certain theory. For example, the ability to understand mathematical laws or plan to read a text, the ability to write several complex essays, the ability to observe or experiment with chemistry, the ability to play a musical instrument, the ability to draw and others are of such skills (Sadigov, 2012: 154-155).

Active forms of work in inculcating life skills in primary school students

In all the mentioned cases, students need to be motivated to purposefully instill life skills. One of the urgent needs of the day is the use of the creative mechanism of motivation by the primary school teacher in the process of applying the listed types of lessons in an interactive form. Because during active learning, i.e. in the process of active learning, there is a need to create motivation for the implementation of interactivity, because motivation is the most complex and important stage of active learning. That is, the further course of an active lesson depends on how motivation is created and carried out. The main feature of motivation is the creation of a problematic situation that gives rise to a number of assumptions.

Motivation is about asking a question that will guide the problem through active learning. It plays a key role in the training process and is a very powerful factor. High motivation in interactive learning leads to faster and easier comprehension of learning outcomes. When motivated, students are very close to solving the problem. However, students feel that they need something to solve the problem. As Davudov points out, this "something" must be the subject of a new lesson (Davydov, 1972: 
182). From this point of view, motivation is the main stage of the lesson (Davydov, 1986: 463).

The emergence of real cognitive motivation (desire to acquire knowledge) is the main advantage of active interactive learning. This is based on the ability of students to resolve real contradictions in the course of cognitive activity. Emotions arising from real contradictions mobilize mental resources, stimulate cognitive activity, allow them to concentrate for a long time. Information is not acquired in a "ready" way, but in the process of independent discovery, the process of new assimilation is not passive, but active (Veysova, 2007: 39).

The main feature of the interactive teaching method is that it assumes the passivity of students and creates conditions for the formation of their thinking and creative abilities in order to increase the quality of teaching. Modern teaching technologies require the teacher to be active in preparing for the lesson, and students in the classroom. With the help of modern learning technologies, the educational, developmental and pedagogical functions of training become more pronounced and improve the quality of training (http://aztehsil.com/news/6687-nnvi-v-interaktiv-təlimmetodlarnn-mqayisli-thlili.html).

There are a number of factors to be taken into account when creating motivation.These factors can be systematized as follows:

1. The material should be unusual, make the student think, and focus on the development of independent thinking;

2. Sesearch methods and forms of material should motivate students to activity and research;

3. Assumptions should be tested and presented;

4. Creating maximum opportunities for creativity;

5. The teacher should ask the right guiding questions, support and guide the answers (Hajiyeva, 2006: 13-14).

For example, in the textbook of "Life Knowledge" the pictures for the theme "I am a living being" intended for the first lesson are given on the relevant page of the textbook. Below the pictures we can see the sentence "With the help of my senses I feel those around me and get information about them". This sentence allows students to address the teacher with certain questions. Based on this, students begin to look for answers to asked questions to explain the functions of their body organs. Therefore, asking the students the questions like "What is the purpose of the ears?", "What is the function of the eyes?", "What do our hands serve?", "What do we do with our mouths?", "What is the function of our nose?" teacher helps the students to determine the functions of their sense organs. In this case, the answers of individual students are interpreted comparatively. The class teacher, who summarizes the comparisons, eventually fulfills the shortcomings in the students' answers. At this time, students acquire new knowledge about their senses. By mastering such knowledge, they lay the foundation for the development and formation of first and new life skills.

So, the correct motivation makes students accustomed to asking questions about the topic being analyzed and taught. The asked questions and the given answers lay the foundation for motivating new life skills to be created. Therefore, primary school teachers must learn in detail the ways of motivation creation and be able to apply them. In the process of teaching any subject on life knowledge lessons the interpretation of the symbolic material, encouraging to ask the questions, and use ambiguous solutions to the problem is considered useful.

As, their conducting as the following system is considered one of the components of the active forms of work.

I. Interpretation of symbolic material. Symbolic material can include photos, posters, symbols, a piece of art, a riddle, etc. The teacher demonstrates and presents the material, addresses the class with questions such as, "What does this mean?" and "How can you explain this?".

II. Encouragement to ask questions. There are 3 types of questions that actualize the thinking process.

1. "What do we know and do not know about life skills?", "What else would we like to know about life skills?" After asking questions, the teacher directs the students' thinking in the right direction and guides them. For this purpose, auxiliary questions can be asked, and terms can be used to help clarify the problem raised in the question.

2. Mainly questions with two or more answers are used. Because using questions with specific answers is not enough to search and research. words.

3. Questions are asked mainly with the help of key

III. Unambiguous solution of the problem.

Just as there are several reasons for any accident, it is necessary to solve all the problems for gaining its solution, and questions should be asked in this direction (Hajiyeva, 2006: 14).

The creation of motivation in this system will help to instill in students life skills in the process of work carried out on the basis of any active forms of work.

In the process of teaching life skills, it is useful to use a number of active forms of work to develop students' life skills. The most necessary life skills can be formed in young schoolchildren by using active forms of work, such as group work and pair work.

Working in groups allows all students in the classroom to mobilize their skills actively, helping students to behave confidently. The group form of teaching involves the rejection of the teacher-student dialogue and the transition to the teacher-group-student trinity. This method not only teaches students to solve problems together, but also develops parts of the team that serve to reveal life skills in students. At the same time, there are 3 options for organizing work in groups:

1. The groups work on a chosen topic based on different learning materials. Under such conditions, they acquire new skills.

2. If the material is important or not large enough to be distributed among groups, then all groups do the same thing at the same time. At the same time, they acquire rich skills.

3. Using the method of rotation, consistently replacing each other and working over the same material, groups acquire life skills (Hajiyeva, 2006: 15).

As you can see, group work has many advantages. First of all, the interactive activity of the class is ensured 
during the organization of group work. Secondly, opportunities are expanding in the field of popularization of the teacher's work to reveal life skills. Third, effective discussion and comparisons by students in designated groups increase their cognitive activity. At the same time, there are more opportunities to discover new life skills. You can create a work form for 4, 5 or even 6 groups in the class. Groups are placed at tables separately. It is better not to differ in the number of boys and girls in groups. It is more appropriate to change the members of the different groups at the different lessons. All this gives reason to say that the purposeful, planned formation of groups, organized activities create a basis for the discovery of a number of skills and abilities in students, the identification of talented students. The formation of groups ensures the activation of passive students. The most important thing in working with groups is to develop students' ability to express new ideas, make judgments. However, these skills manifest as vital skills.

Working in pairs is also very important. In this form of work, students work in pairs to:

1. Assist each other in the implementation of any task, decision, problem;

2. Exchange views on the results of their work (class or homework);

3. To carry out mutual assessment, mutual inspection.

These cases are also necessary as the students are demanded to compare and coordinate the different views, they have to demonstrate mutual assistance (strong pair -

\section{References}

1. Huseynzade, R., Akbarov, N. (2013). Organization of pedagogical process in school. Methodical aids. Baku.

2. Hajiyeva, H. M., Musayeva, Z. Y., Akhmadova, Z. Z., Huseynova, G. H., Verdiyeva, G. E. (2006). Education based on life skills. (Textbook for primary school teachers of secondary schools). Baku, Muterjim.

3. Sadigov, F. B. (2012). Pedagogy (Textbook). Baku, Adiloghlu. weak student). Working in pairs allows students to understand each other's perspectives better, cooperate, and realize their responsibilities to each other (Hajiyeva, 2006: 15-16).

This form of work helps students to develop their life skills. Because the didactic materials prepared for couples contain ideas, thoughts, life events, customs, traditions, national-moral values, socio-economicpolitical facts, achievements in the field of industry and construction, information on the progress of our country, which guides them to instill life skills. These factors help to identify, develop and shape the life skills of the students involved in the pair group.

Each lesson, based on modern requirements, should try to convey to students the beauty and harmony of life as a new discovery, to give them the deep knowledge necessary for the formation of the ability. As the famous French writer Anatole Franz put it: "Lessons should be organized in such a way that not a single student sat in the classroom without work and ideas" (Veysova, 2007: 76).

\section{Conclusion}

In the process of teaching life knowledge lesson the students' life skills can be extracted, developed and shaped through teaching any topic, analyzing topics, asking questions, getting answers, creating problem situations, and in implementing active work forms through using of teaching methods, new teaching technologies, pedagogical innovations and the power of computer technologies.

4. Veysova, Z. (2007). Active interactive learning. Aid for teachers. Baku.

5. Davydov, V. V. (1986). Problems of the developing education. Moscow, Pedagogy.

6. Davydov, V. V. (1972). Types of communication in training. Moscow: Pedagogy. Retrieved from http://aztehsil.com/news/6687-nnvi-v-interaktiv-təlimmetodlarnn-mqayisli-thlili.html

\section{Зейнаб Мехдиева, \\ вчитель Нахчиванського учительського інституту, вул. Гейдара Алієва, 1, Нахчиван, Азербайджанська Республіка}

\section{ВИКОРИСТАННЯ АКТИВНИХ РОБОЧИХ ФОРМ У ВИХОВАННІ В МОЛОДШИХ ШКОЛЯРІВ ЖИТТЕВИХ НАВИЧОК}

У статті широко проаналізовано досвід використання активних форм роботи у вихованні в учнях початкових класів загальноосвітніх шкіл життєвих навичок. Класифіковано типи уроків, в яких з'ясовано сутність видів активних уроків. Зазначається, що досягти формування життєвих навичок учнів можливо завдяки використанню активних форм роботи в процесі навчання, організованих для всіх типів сучасних уроків. Для цього необхідно в ході активного уроку створювати мотивацію, використовувати проблемні ситуації. Ми знаємо, що навчання головним чином мотивує мислення. Постановка завдання учням спонукає їх мислити i створює умови для формування їх мислення. Вирішуючи проблему, у дітей формуються позитивні емоції та ентузіазм до навчання. Використання активних форм роботи для виховання життєвих навичок також створює основу для підвищення пізнавальної активності учнів. У зв'язку з цим також важливо виконувати проблемні завдання. Таким чином, створення основи для набуття нових знань та створення умов для активного розуміння знань відіграє ключову роль у реалізації проблемних завдань. Стаття підсумовує використання інтерактивних методів навчання, а також зосереджує увагу на основних аспектах процесу діяльності вчителів початкових 
класів. Таким чином, у статті відображено використання активних форм роботи в процесі викладання предмета «життєві знання» при розкритті життєвих навичок учнів.

Ключові слова: початкова школа, учень, інтерактивний метод навчання, життєві навички, активні форми роботи, школа, урок.

Подано до редакиіï 02.11.2020

УДК: 37.091.3:7.071.2:796.015.52

DOI: https://doi.org/10.24195/2414-4665-2020-4-2

Валентина Тодорова, доктор наук з фізичного виховання і спорту, дочент кафедри гімнастики та спортивних єдиноборств, Державний заклад «Південноукраӥнський наџіональний педагогічний університет імені К. Д. Уиинського», вул. Старопортофранківська, 26, м. Одеса, Україна,

Валентина Сосіна, кандидат педагогічних наук, професор, завідувач кафедри хореографії та мистеитвознавства, Львівський державний університет фізичної культури імені Івана Боберського, вул. Костюшка, 11, м. Львів, Україна,

Валентина Вартовник,

доиент кафедри хореографії та мистеитвознавства,

Заслужений прачівник культури України,

Львівський державний університет фізичної культури імені Івана Боберського, вул. Костюшка, 11, м. Львів, Україна,

Наталія Пугач,

кандидат наук з фізичного виховання і спорту, доцент кафедри хореографії та мистецтвознавства, Львівський державний університет фізичної культури імені Івана Боберського, вул. Костюшка, 11, м. Львів, Україна,

олена Погорелова, кандидат філософських наук, доцент кафедри гімнастики та спортивних єдиноборств, Державний заклад «Південноукраӥнський начіональний педагогічний університет імені К. Д. Уиинського», вул. Старопортофранківська, 26, м. Одеса, Україна

\section{РОЗВИТКУ СИЛОВИХ ЯКОСТЕЙ У ТАНЦЮРИСТІВ ЗАСОБАМИ ХОРЕОГРАФІЧНОЇ ПІДГОТОВКИ}

У статті представлені результати вивчення особливостей розвитку різних силових якостей у танцюристів - представників народно-сценічного танцю. Мета роботи - розробити програму розвитку силових якостей з використанням засобів хореографії у танцюристів-народників. У дослідженні було використано групу теоретичних і емпіричних методів. Було проведено педагогічні спостереження на навчальних заняттях з танцุюристами 12-15 років, опитування педагогів і тренерів щุодо особливостей розвитку силових якостей, тестування показників різних силових якостей у підлітків 12-15 років, які займаються народно-сценічним танцем у Заслуженому ансамблю танию Украӥни «Юність» $і$ в школі народного таниюю, народного ансамблю танцюю «Серпанок» (м. Львів). Це дало змогу розробити програму розвитку силових якостей з урахуванням їх різновидів, щзо необхідні у народно-сценічних таниях. У якості основних засобів їх розвитку у програмі були викорис-тані вправи народно-сценічного танцю, при доборі яких враховувалася можливість забезпечення локального, регіонального чи загального впливу на опорно-руховий апарат та необхідність точного дозування навантаження. Виявлено позитивний вплив розробленої програми на розвиток різних силових якостей танцюристів. Отримані результати можуть бути використані в практиці роботи педагогів хореографічних колективів народно-сиенічного танц̧ю.

Ключові слова: силові якості, танцюристи, народно-сценічний танецьь, програма розвитку. 